\title{
Comparative analysis of DNA alkylation by conjugates between pyrrole-imidazole hairpin polyamides and chlorambucil or seco-CBI.
}

\section{$\operatorname{AUTHOR(S):~}$}

Minoshima, Masafumi; Bando, Toshikazu; Shinohara, Ken-Ichi; Kashiwazaki, Gengo; Nishijima, Shigeki; Sugiyama, Hiroshi

\section{CITATION:}

Minoshima, Masafumi ...[et al]. Comparative analysis of DNA alkylation by conjugates between pyrrole-imidazole hairpin polyamides and chlorambucil or seco-CBI.. Bioorganic \& medicinal chemistry 2010, 18(3): 1236-1243

\section{ISSUE DATE:}

2010-02-01

URL:

http://hdl.handle.net/2433/97888

\section{RIGHT:}

c 2009 Elsevier Ltd. All rights reserved.; この論文は出版社版でありませ ん。引用の際には出版社版をご確認ご利用ください。; This is not the published version. Please cite only the published version. 


\title{
Comparative Analysis of DNA Alkylation by Conjugates between Pyrrole- Imidazole Hairpin Polyamides and Chlorambucil or seco-CBI
}

\author{
Masafumi Minoshima ${ }^{1}$, Toshikazu Bando ${ }^{1}$, Ken-ichi Shinohara ${ }^{1}$, Gengo Kashiwazaki $^{1}$, Shigeki Nishijima ${ }^{1}$, and \\ Hiroshi Sugiyama ${ }^{1,2 *}$ \\ ${ }^{1}$ Department of Chemistry, Graduate School of Science, Kyoto University, Kitashirakawa-Oiwakecho, Sakyo-Ku, Kyoto, \\ 606-8502, Japan, ${ }^{2}$ Institute for Integrated Cell-Materials Science (iCeMS).
}

RECEIVED DATE ;E-mail: hs@kuchem.kyoto-u.ac.jp

\begin{abstract}
We investigated sequence-specific DNA alkylation using conjugates between the N-methylpyrrole (Py)-N-methylimidazole (Im) polyamide and the DNA alkylating agent, chlorambucil, or 1-(chloromethyl)-5-hydroxy-1,2-dihydro-3H-benz[e]indole (seco-CBI). Polyamide-chlorambucil conjugates 1-4 differed in the position at which the DNA alkylating chlorambucil moiety was bound to the PyIm polyamide. High-resolution denaturing polyacrylamide gel electrophoresis (PAGE) revealed that chlorambucil conjugates 1-4 alkylated DNA at the sequences recognized by the Py-Im polyamide core moiety. Reactivity and sequence specificity were greatly affected by the conjugation position, which reflects the geometry of the alkylating agent in the DNA minor groove. Polyamide-seco-CBI conjugate $\mathbf{5}$ was synthesized to compare the efficacy of chlorambucil with that of seco-CBI as an alkylating moiety for Py-Im polyamides. Denaturing PAGE analysis revealed that DNA alkylation activity of polyamide-seco-CBI conjugate $\mathbf{5}$ was similar to that of polyamidechlorambucil conjugates $\mathbf{1}$ and $\mathbf{2}$. In contrast, the cytotoxicity of conjugate $\mathbf{5}$ was superior to that of conjugates 1-4. These results suggest that the seco-CBI conjugate was distinctly active in cells compared to the chlorambucil conjugates. These results may contribute to the development of more specific and active DNA alkylating agents.
\end{abstract}

\section{Introduction}

DNA targeting with small molecules has been studied for several decades $^{1}$. DNA alkylating agents have been used as anticancer agents as they induce sufficient DNA damage to kill cancer cells ${ }^{2}$. Conjugates between small molecules and alkylating agents have superior DNA binding affinity to that of alkylating agents alone. Conjugates between distamycin A, a DNA minor groove binder, and nitrogen mustard DNA alkylating agents have superior DNA alkylating activity and cytotoxicity against cancer cells $\mathrm{s}^{3}$. Antibiotics such as $\mathrm{CC}-1065$ and duocarmycin derivatives are strong alkylating agents that bind to $\mathrm{DNA}^{4}$. These compounds alkylate at the N-3 position of adenines flanked by AT-rich sequences. Despite the effort that has been devoted to the development of DNA alkylating agents, their severe side effects have not been overcome.

To address this problem, our group focused on the introduction of sequence specificities into DNA alkylating agents. Minor groovebinding hairpin polyamides that contain $N$-methylpyrrole (Py)- $N$ methylimidazole (Im) and uniquely recognize each of the four Watson-Crick base pairs were developed by Dervan et al ${ }^{5}$. Pairing of Im opposite Py targets the $\mathrm{G}-\mathrm{C}$ base pair, and Py-Im targets the $\mathrm{C}-\mathrm{G}$ base pair. Py-Py targets the T-A and A-T base pairs. It has been demonstrated that Py-Im hairpin polyamides that bind competitively to transcription regulatory sequences inhibit target gene expression ${ }^{6}$. We demonstrated that hybrid molecules consisting of duocarmycin A and Py-Im hairpin polyamides alkylated sequences predetermined by the recognition rules of the Py-Im polyamides ${ }^{7}$. Furthermore, we showed that introduction of a vinyl linker between the polyamides and cyclopropapyrroloindole (CPI) resulted in efficient alkylation of double-stranded DNA and improved cytotoxicity against cancer cells $^{8}$. A more chemically stable indole linker and the synthetic alkylating agent 1,2,9,9a-tetrahydrocyclopropa[1,2-c]benz[1,2- $e$ ]indol-4-one $(\mathrm{CBI})^{9}$. were recently introduced for the design of sequence-specific DNA alkylating agents. This type of alkylating agent has superior stability, and can be synthesized to contain longer recognition sequences than other types of alkylating agents ${ }^{10}$. We have demonstrated that alkylation at the coding region of a template strand produces truncated $\mathrm{mRNA}^{11}$. We have also demonstrated that selective alkylation at the coding region of a template strand using Py-Im polyamides results in silencing of reporter genes (luciferase and GFP) ${ }^{12}$.

Dervan et al. constructed a small library of conjugates between polyamides with different recognition sequences and chlorambucil $^{13}$. One of these conjugates arrested the growth of several cancer cell lines. They demonstrated selective alkylation at the coding region of the histone $h 4 c$ gene and inhibition of its expression, which indicates that sequence-specific DNA alkylating polyamides are promising gene-targeting drugs for cancer chemotherapy ${ }^{14}$. However, little is known about conjugates between the hairpin polyamide and chlorambucil. In this report, we present a comprehensive analysis of the DNA alkylating activities of hairpin polyamides conjugated with chlorambucil at various positions, their sequence specificities, and their effects on cell viability. We also compared the polyamide-chlorambucil conjugates to a polyamide-seco-CBI conjugate.

\section{Molecular Design and synthesis}

We designed agents in which the Py-Im polyamide was conjugated with chlorambucil at different positions: C-tail (1), Ntail (2), N-tail with a $\beta$-alanine linker (3), and turn (4) (Figure 1a). To investigate the effect of the position of the conjugate, all Py-Im polyamides were designed to recognize the same sequence (Figure 1b). The core moiety of the Py-Im polyamide recognizes the seven base pair sequence, 5'-WGCWGWC-3' $(\mathrm{W}=\mathrm{A}$ or $\mathrm{T})$. All conjugates had one cationic tertiary amino group at the C-tail. 
Conjugate 4 had an (R)- $\alpha$-diaminobutyric acid as a turn moiety. This turn moiety has more specific DNA alkylation activity than (R)- $\gamma$-diaminobutyric acid and has more efficient DNA alkylation activity than the stereochemically inversed (S)- $\alpha$-diaminobutyric acid turn $^{15}$. We also designed a Py-Im polyamide-seco-CBI conjugate (5) with an indole linker (Figure 1a). Conjugate 5 has the identical recognition sequences as other polyamide chlorambucil conjugates. The Py-Im polyamides were synthesized using Fmoc-based solid-phase synthesis ${ }^{16}$. Polyamides with amino group were coupled with chlorambucil to produce conjugates 1-4. A polyamide with carboxylic acid was coupled with indole-secoCBI alkylating unit to produce the conjugate 5 (schemes are shown in supporting information $)^{17}$. All conjugates were purified by HPLC, and confirmed by ESI-TOF-MS or NMR.

a)

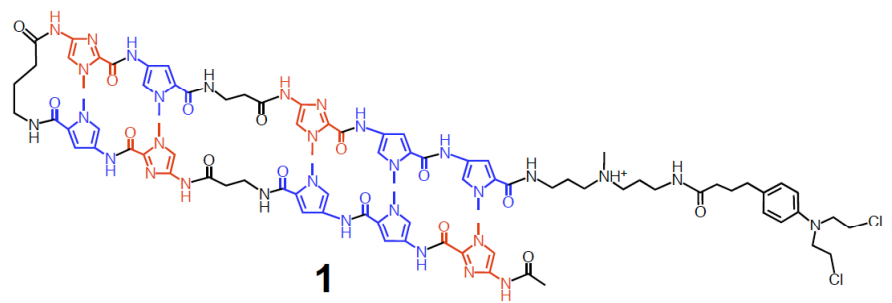

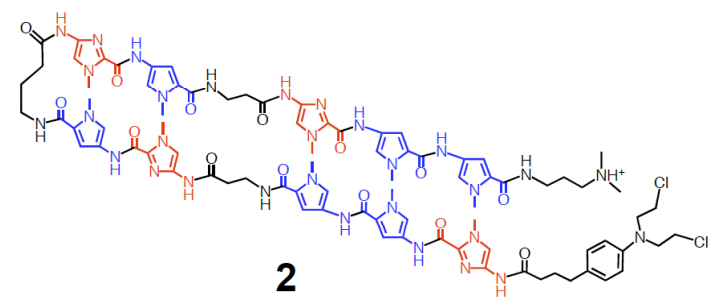

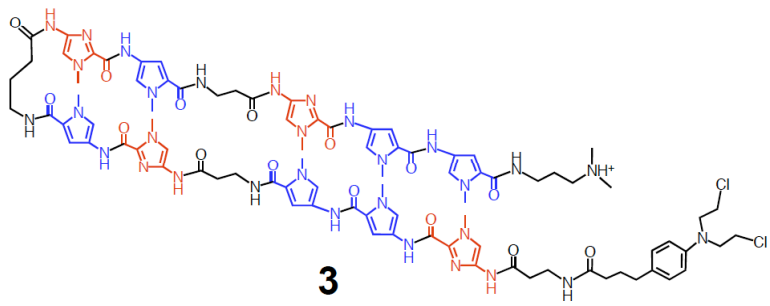

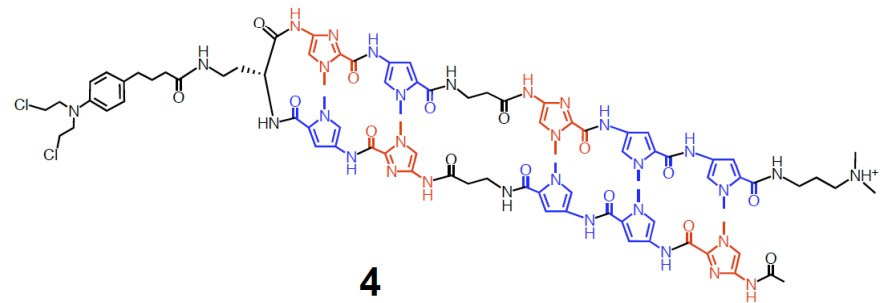

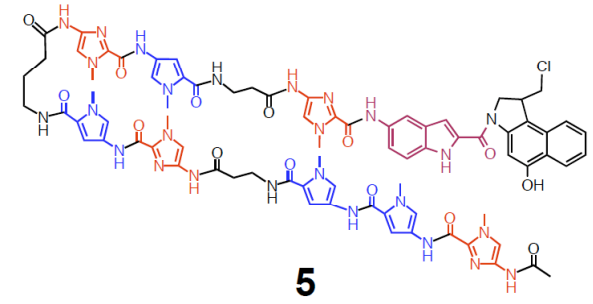

b)

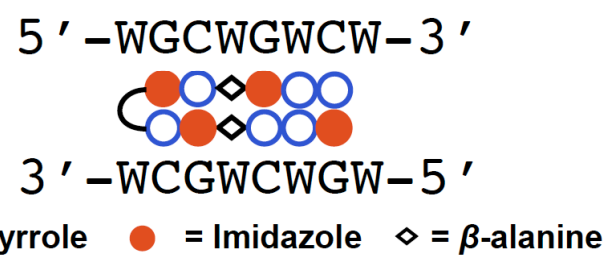

$O=$ Pyrrole $\bigcirc=$ Imidazole $\diamond=\beta$-alanine

$C=y$-aminobutyric acid

Figure 1. (a) A chemical structure of Py-Im polyamide-chlorambucil conjugates 1-4, Py-Im polyamide-seco-CBI conjugate 5. (b) Schematic representation of binding by polyamide at consensus seven-base-pair recognition sequence. $\mathrm{W}$ indicates $\mathrm{A}$ or $\mathrm{T}$ base.

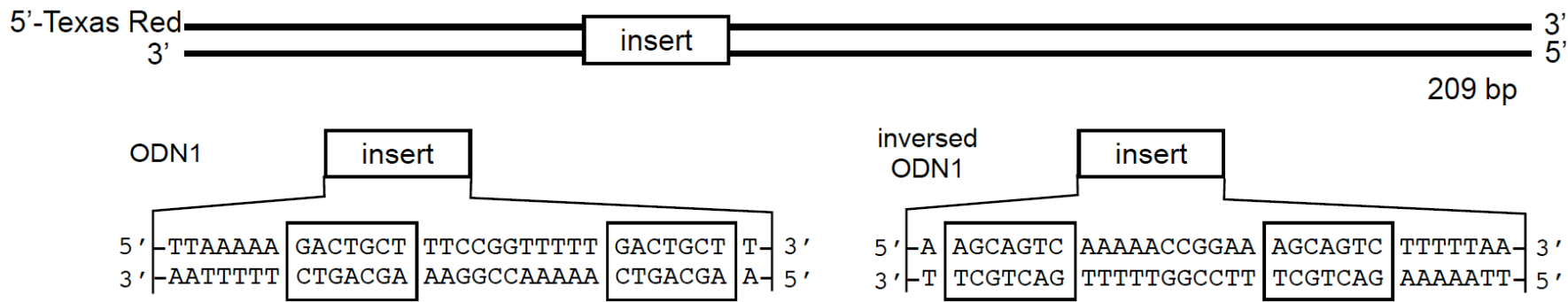

Figure 2. Illustration of the 209 base pair DNA fragment with the position of the sequence indicated. The recognition sites for polyamide core moiety are boxed. 


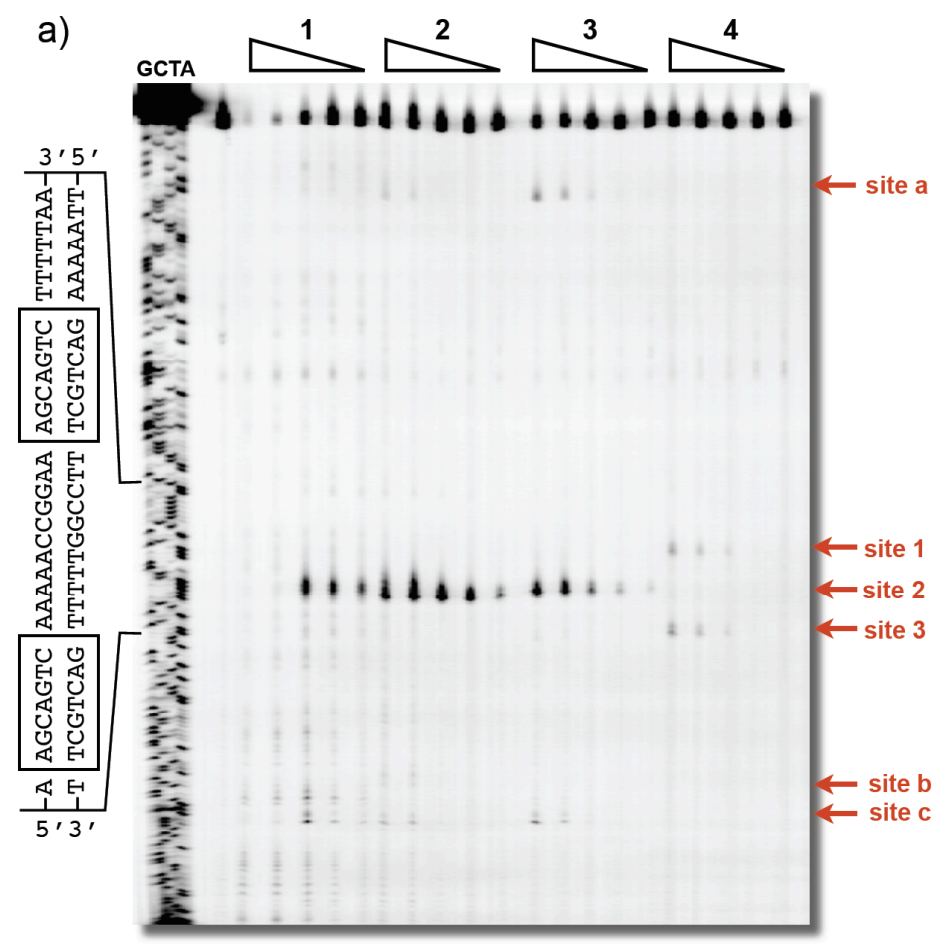

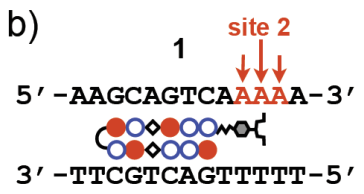

$2 \downarrow \downarrow \downarrow$

5' -AAGCAGTCAAAAA-3'

$\infty>000$ on

3'-TTCGTCAGTTTTT-5'
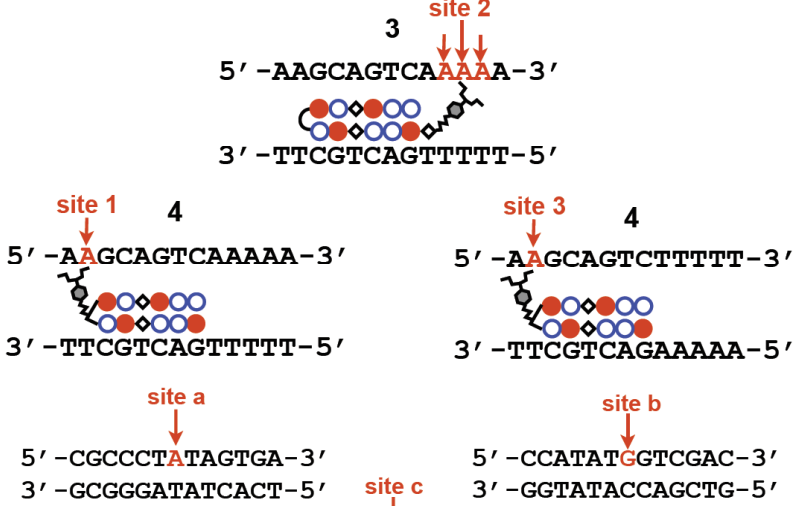

$3^{\prime}$-TTCGTCAGAAAAA-5

3'-GCGGGATATCACT-5'

$$
5 ' \text {-TCTCCCATATGGT- } 3 \text { ' }
$$

3'-AGAGGGTATACCA-5'

\begin{tabular}{|c|c|c|}
\hline$O=$ pyrrole & = imidazole & $C=y$-aminobutyric acid \\
\hline$\diamond=\beta$ & worh = chlorambucil & $\langle=a$-diaminobutyric acid \\
\hline
\end{tabular}

Figure 3. (a) Thermally induced strand cleavage of 5'-Texas Red-labeled 209 bp DNA fragments inserted ODN1 by polyamide-chlorambucil conjugates $1-$ 4. The concentrations of conjugates were 1000,500,100,50, and $10 \mathrm{nM}$. Alkylation sites are shown in red arrows. (b) Schematic representation of the recognition of alkylation sites by $\mathbf{1 - 4}$. The arrows indicate the site of alkylation and the alkylating bases are shown in red.

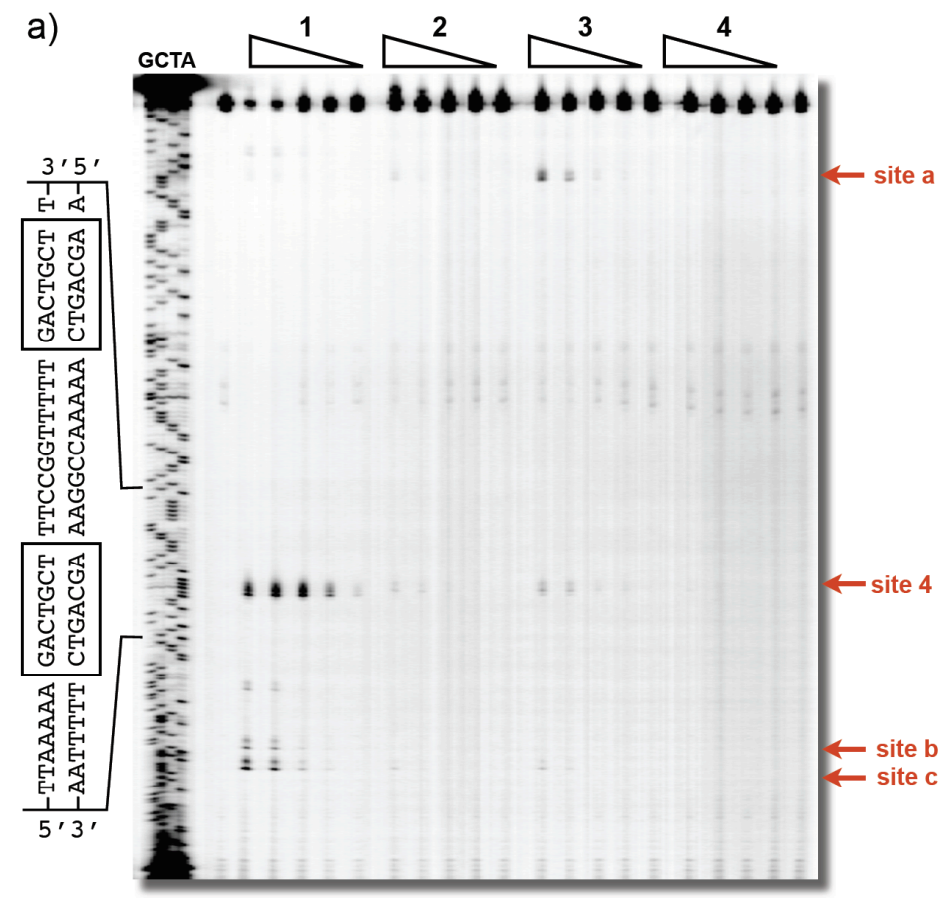

b)
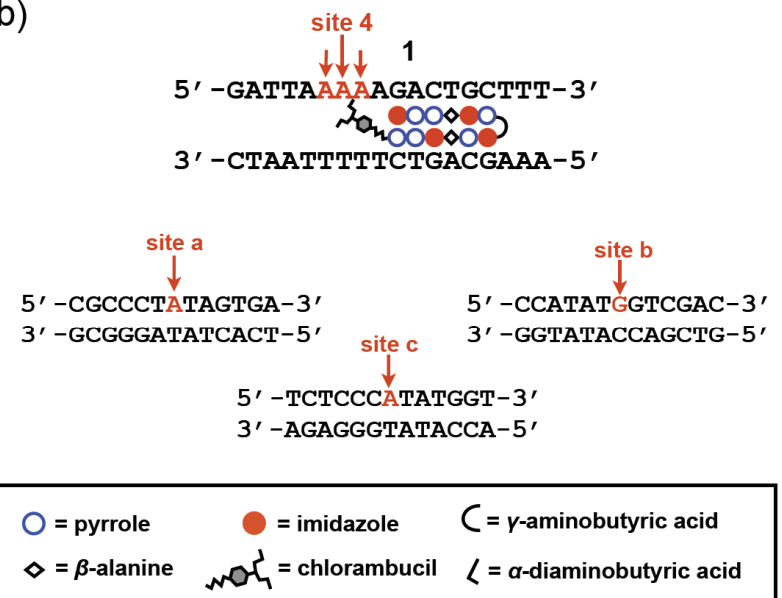

Figure 4. (a) Thermally induced strand cleavage of 5'-Texas Red-labeled 209 bp DNA fragments inserted inversed ODN1 by polyamide-chlorambucil conjugates 1-4. The concentrations of conjugates were $1000,500,100,50$, and $10 \mathrm{nM}$. Alkylation sites are shown in red arrows. (b) Schematic representation of the recognition of alkylation sites by 1-4. The arrows indicate the site of alkylation and the alkylating bases are shown in red. 


\section{High-resolution denaturing PAGE analysis of labeled DNA fragment alkylated by conjugates 1-4}

The sequence-selective DNA alkylation activity of chlorambucil conjugates 1-4 was investigated using a 5'-Texas Red-labeled DNA fragment and an automated DNA sequencer as described previously $^{18}$. The 209 bp DNA fragment was prepared by inserting ODN1 (Figure 2), including two recognition sequences of the polyamides and several adenines at the 5 '- and 3 '-side of the recognition sequences. Nitrogen mustard DNA alkylating agents predominantly react at guanine bases such as the N7 positions; however, when located at the minor groove, they react mainly at adenine bases such as the $\mathrm{N} 3$ positions ${ }^{3}$. Alkylation was carried out at $23{ }^{\circ} \mathrm{C}$ for $18 \mathrm{~h}$, followed by quenching with calf thymus DNA. The samples were heated at $95{ }^{\circ} \mathrm{C}$ under neutral conditions for $10 \mathrm{~min}$. The alkylation sites were visualized by thermal cleavage of the DNA strand. Under these heating conditions, all the purine $\mathrm{N} 3$ alkylated sites in the DNA produced cleavage bands on the gel. The results of sequencing gel analysis of DNA fragments alkylated by conjugates 1-4 after heat treatment are shown in Figure 3. Figure 3 shows that DNA alkylation by conjugates $\mathbf{1}, \mathbf{2}$, and 3 occurred mainly at sites located on the $3^{\prime}$ side of adenines recognized by the polyamide, 5'AGCAGTCAAAAA-3' (site 2). Conjugates 1, 2, and 3 showed high alkylating activities at nanomolar concentrations. At the highest concentration of conjugate $\mathbf{1}$, all the DNA bands were disappeared probably because of the non-specific alkylation at many sites. On the other hand, slight DNA alkylation by conjugate 4 occurred at two sites located on the $5^{\prime}$-side of the recognition sequence, 5'-AGCAGTC-3' (sites 1 and 3). This alkylation result for conjugate 4 correspond with those of a previous report on polyamide-chlorambucil conjugates at the hairpin turn position ${ }^{14}$. Conjugate 4 resulted in little alkylation, even at a concentration of $1 \mu \mathrm{M}$.

To investigate alkylation of the complementary strand, we used conjugates 1-4 and a 209 bp DNA fragment inserted inversed ODN1 sequence (Figure 2). The results of sequence gel analysis are shown in Figure 4. Surprisingly, conjugate 1 showed efficient

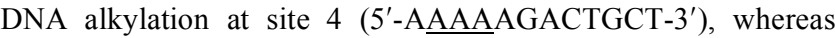
conjugates $\mathbf{2}$ and $\mathbf{3}$ only alkylated this site slightly. Conjugate $\mathbf{4}$ did not provide distinct gel bands for any site. This indicates that conjugate 1 alkylates adenines in both strands adjacent to the recognition sequence of the Py-Im polyamide, whereas conjugates 2-4 selectively alkylate only one strand.

\section{DNA alkylation activity and sites of polyamide- chlorambucil conjugates 1-4}

The denaturing PAGE experiment revealed that the activity and site of DNA alkylation are dependent on the position of the conjugate between the DNA alkylating chlorambucil moiety and the polyamide. Conjugates at the $\mathrm{C}$-tail and $\mathrm{N}$-tail positions of the polyamide (1-3) had potent DNA alkylating activity, whereas the conjugate at the hairpin turn position (4) had slight DNA alkylating activity. In this experiment, the tail position of polyamides binding to the predetermined sequence was located at five adenine tracts. This sequence may allow efficient alkylation activity by the DNA alkylating agents. Moreover, the difference of DNA binding affinity of polyamides may also reflect the alkylation activity. Dervan and co-workers reported that polyamides with $\alpha$-turn had lower affinity compared to that of polyamides with $\gamma$-turn ${ }^{19}$. The sequence specificity for the DNA alkylation site differed between conjugates. The geometry of chlorambucil conjugated with the hairpin polyamide determines whether the alkylation site will lie on the $3^{\prime}$-side (conjugates 1-3) or the 5 -side (conjugate 4). These results indicate that the microenvironment of the DNA minor groove to which polyamides bind is critical for activity and sequence specificity. Figure 5 shows schematic representations of the DNA recognition and alkylation sites of conjugates $\mathbf{1}-\mathbf{4}$.

The conjugate at the C-tail of the polyamide (1) efficiently alkylated adenines on both strands two to four bases from the sequence recognized by the polyamide core moiety. In this conjugate, the chlorambucil moiety is flexibly conjugated with the cationic tertiary amine, which may have enabled DNA alkylation of adenines in both strands.

The conjugate at the $\mathrm{N}$-tail of the polyamide (2) efficiently alkylated adenines on the 3 '-side one to three bases from the sequence recognized by the polyamide core moiety. Moreover, conjugate 2 exclusively alkylated the adenines in the 5'-AAAAA$3^{\prime}$ sequence, not the adenines in the $3^{\prime}$-AAAAA- 5 ' sequence. This one-way direction was observed for several minor groove binder nitrogen mustard conjugates. For example, tallimustine (FCE24517) alkylates the specific sequence 5'-TTTTPuA-3', where Pu $=\mathrm{G}$ or $\mathrm{A}^{3 \mathrm{c}}$.
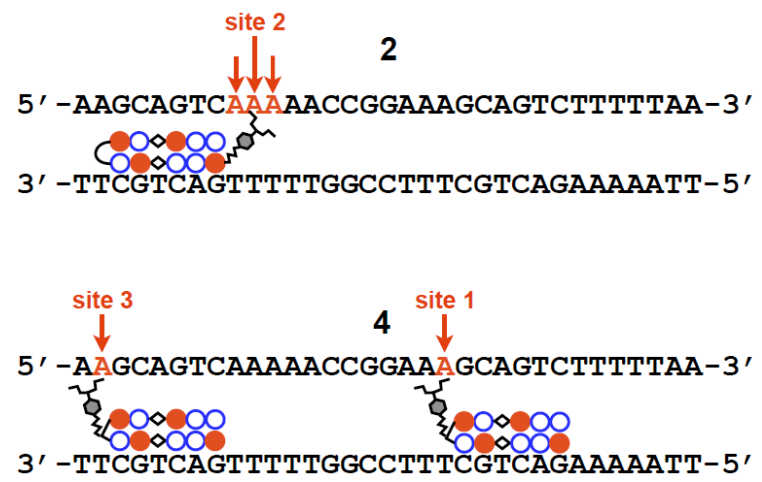

\section{$O=$ Pyrrole $O=$ Imidazole $C=\gamma$-aminobutyric acid $<=\alpha$-diaminobutyric acid $\diamond=\beta$-alanine woh $^{\prime}=$ chlorambucil}

Figure 5. Schematic representations of the alkylation sites of conjugates $\mathbf{1 - 4}$. Arrows indicate alkylation sites corresponding to the sites presented in Figure 3 and 4 . 


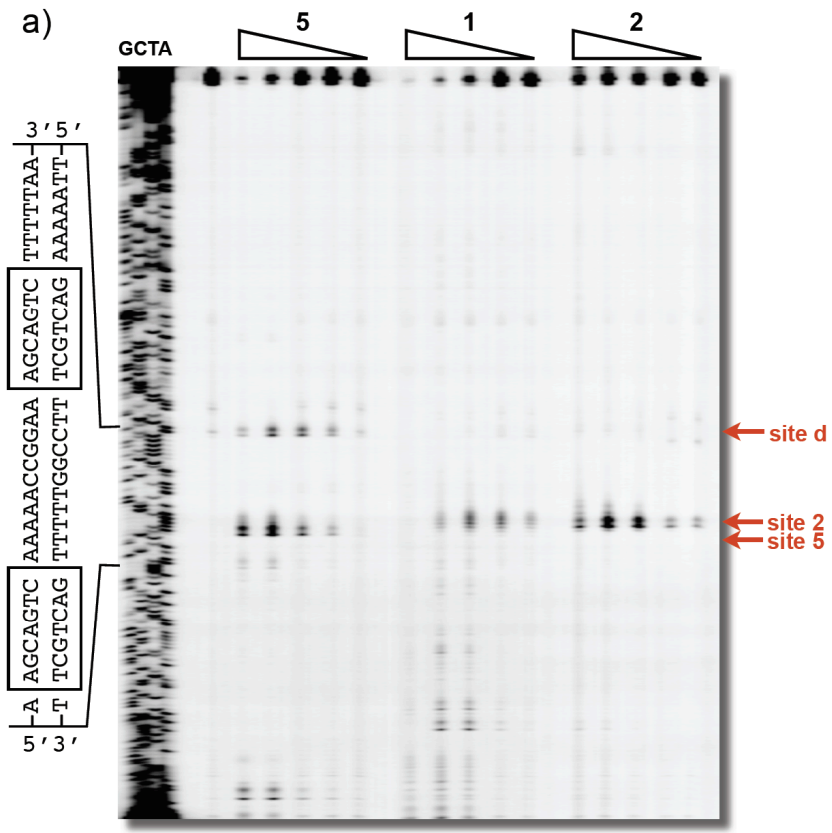

b)
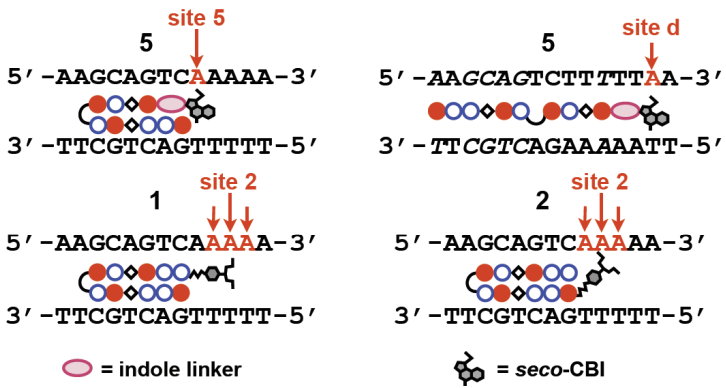

Figure 6. (a) Thermally induced strand cleavage of 5'-Texas Red-labeled 209 bp DNA fragments inserted ODN1 by polyamide-chlorambucil conjugates 1, 2, and polyamide-seco-CBI conjugate 5 . The concentrations of conjugates were $1000,500,100,50$, and $10 \mathrm{nM}$. (b) A schematic representation of the alkylation sites of the polyamide-seco-CBI conjugate 5. Arrows indicate alkylation sites corresponding to the sites presented in Figure 6a.

The conjugate at the $\mathrm{N}$-tail of the polyamide via a $\beta$-alanine linker between the polyamide and chlorambucil (3) showed the similar alkylating property as $\mathbf{2}$, exclusively alkylating the adenines in the 5'-AAAAA-3' sequence. Conjugate 3 slightly reduced activity at the $3^{\prime}$-side two to four bases from the recognition sequence because $\beta$-alanine acts as a one-base spacer.

The conjugate at the (R)- $\alpha$-diaminobutyric acid hairpin turn of the polyamide (4) slightly alkylated specific adenines on the 5 'side according to the sequence recognized by the hairpin turn moiety of the polyamide. Dervan and co-workers also demonstrated highly selective DNA alkylation by a polyamide-chlorambucil conjugate at the hairpin turn position ${ }^{15}$. Gottesfeld and co-workers revealed that this type of conjugate has interesting biological effects $^{13,14}$.

\section{DNA alkylation activity and sites of a polyamide- seco-CBI conjugate 5}

There are several reports on conjugates between the Py-Im polyamide and alkylating agents ${ }^{20}$, but a comparison between their properties is lacking. Then, we examined alkylation by the polyamide-seco-CBI conjugate (5) and polyamide-chlorambucil conjugates 1 and 2 using a 5'-Texas Red-labeled 209 bp DNA fragment. The results of sequencing gel analysis of the alkylated DNA fragment after heat treatment are shown in Figure 6a. Conjugate 5 mainly alkylated site 3 (5'-AGCAGTCAAAAA- $\left.3^{\prime}\right)$, corresponding with our previous results (Figure $6 \mathrm{~b}$ ). Conjugate 5 also alkylated site d (5'-TCTTTTT $\left.\underline{A} A-3^{\prime}\right)$, an AT-rich sequence. The alkylation activity of conjugate $\mathbf{5}$ was similar to that of conjugate $\mathbf{2}$, indicating that both conjugates have similar alkylation activity. Tight binding to the DNA minor groove and a location of alkylating seco-CBI moiety near the adenines would dramatically improve DNA alkylating activity. The DNA alkylation sites differed slightly between conjugates.

\section{Cytotoxicity against a cancer cell line by conjugates 1-5}

We compared the effects of the conjugates on cell viability by exposing human lymphocyte K562 cells to conjugates 1-5 for 48 h. Cell viability was evaluated using the WST- 8 assay. The concentrations of conjugates $\mathbf{1}$ and $\mathbf{2}$ in the medium containing $1 \%$ DMSO were limited by poor solubility to less than $2.5 \mu \mathrm{M}$. Cytotoxicity results are shown in Supporting Information. Only the seco-CBI conjugate (5) was severely cytotoxic at submicromolar concentrations. Conjugates $\mathbf{1}$ and $\mathbf{2}$ were slightly cytotoxic. Chlorambucil conjugate $\mathbf{3}$ was moderately cytotoxic at micromolar concentrations and conjugate $\mathbf{4}$ was almost nontoxic at a concentration of $10 \mu \mathrm{M}$. We were only able to estimate the $50 \%$ growth inhibition concentrations $\left(\mathrm{GI}_{50}\right)$ for conjugates 3 and 5 ( 8 and $0.06 \mu \mathrm{M}$, respectively; Table 1). cytotoxicity against a cancer cell line differed significantly between the chlorambucil and seco-CBI conjugates. Polyamide-chlorambucil conjugates were cytotoxic at micromolar concentrations, whereas the polyamide-seco-CBI conjugate (5) was potently cytotoxic at submicromolar concentrations. Although DNA alkylating activity was similar among conjugates $\mathbf{1}, \mathbf{2}$, and $\mathbf{5}$ in previous experiment (Figure 6A), the seco-CBI conjugate 5 was over 100-fold more cytotoxic than the chlorambucil conjugates. This difference could have been caused by factors other than DNA alkylating properties against naked DNA fragments, such as stability of an alkylating moiety in an aqueous medium ${ }^{21}$, cell permeability ${ }^{22}$,or repair of damaged $\mathrm{DNA}^{23}$.

Table 1. Estimated the $50 \%$ growth inhibition concentrations $\left(\mathrm{GI}_{50}\right)$ for conjugates 1-5 against K562 cell.

\begin{tabular}{|c|c|c|c|c|c|}
\hline conjugate & $\mathbf{1}$ & $\mathbf{2}$ & $\mathbf{3}$ & $\mathbf{4}$ & $\mathbf{5}$ \\
\hline $\mathrm{GI}_{50}(\mu \mathrm{M})$ & $>2.5$ & $>2.5$ & 8 & $>10$ & 0.06 \\
\hline
\end{tabular}




\section{CONCLUSIONS}

We investigated the DNA alkylation activity, sequence specificity, and cytotoxicity of Py-Im polyamides conjugated with the alkylating agents, chlorambucil or seco-CBI. Chlorambucil conjugates at the $\mathrm{N}$-tail and $\mathrm{C}$-tail positions had high DNA alkylating activities, which were similar to that of the seco-CBI conjugate. A chlorambucil conjugate at a turn position had low DNA alkylating activity, but specifically alkylated adenines located near the turn moiety. These results suggest that the geometry of alkylating agents in the DNA minor groove is important for alkylation activity and sequence specificity. Moreover, the seco-CBI conjugate is superior to chlorambucil conjugates with regard to the cytotoxicity in culture cells. The properties of an alkylating moiety are important determinants of the efficacy of conjugates in cells.

Previously, we demonstrated that the substitution of one Py with an Im changed cytotoxicity against 39 human cancer cell lines ${ }^{24}$. We also demonstrated distinct differences in cytotoxicity between alkylating polyamides in our library ${ }^{25}$. These reports suggest that screening of highly active alkylating polyamides in a library is an alternative approach to elucidating the potential of alkylating polyamides. The construction of small libraries of alkylating polyamides with different recognition sequences and evaluation of their effects against various cancer cell lines is now in progress.

\section{Experiments}

\subsection{General.}

Reagents and solvents were purchased from standard suppliers and used without further purification. Abbreviations for reagents are: Fmoc, fluorenylmethoxycarbonyl; Boc, tert-butoxycarbonyl; TFA, trifluoroacetic acid; DIEA, $N, N$-diisopropylethylamine; DMF, $\quad N, N$-dimethylformamide; HCTU, 1 [Bis(dimethylamino)methylene]-5-chloro-1H-bezotriazolium-3oxide hexafluorophosphate; PyBOP, benzotriazole-1-yl-oxy-trispyrrolidino-phosphonium hexafluorophosphate; TIS, triisopropylsilane. HPLC analysis was performed with a Jasco PU-2080 HPLC pump, a UV-2075 HPLC UV/VIS detector, a Chemcobond 5-ODS-H 4.6 x $150 \mathrm{~mm}$ column (Chemco Scientific). A Chemcobond 5-ODS-H 10 x $150 \mathrm{~mm}$ column (Chemco Scientific) and a YMC-Pack Pro C18 150 x $20 \mathrm{~mm}$ column (YMC) were used in purification of polyamides. NMR spectra were recorded using a JEOL JNM-FX 400 nuclear magnetic resonance spectrometer with tetramethylsilane as internal standard. Proton NMR spectra were recorded in parts per million (ppm) downfield relative to tetramethylsilane. The following abbreviations apply to spin multiplicity: s (singlet), d (doublet), t (triplet), q (quartet), qu (quintet), m (multiplet), and br (broad). Electrospray ionization mass spectrometry (ESI-MS) and electrospray ionization time-of-flight mass spectrometry (ESITOF-MS) were performed using API 150 (PE SCIEX) and BioTOF II (Bruker Daltonics) mass spectrometers. PCR amplification and DNA sequencing was carried out using the Dice mini thermal cycler (Takara), GoTaq Green Master Mix (Promega), and the Thermo Sequenase core sequencing kit (GE Healthcare). Loading dye was prepared with formamide and fuchsin red (Merck). The 5'-Texas Red-modified DNA oligomer (19 mer) was obtained from Sigma Genosys Co. Ltd. The 50\% Long Ranger ${ }^{\mathrm{TM}}$ gel solution was obtained from Lonza Co. Ltd. Polyacrylamide gel electrophoresis was performed using a HITACHI SQ5500-E DNA sequencer.
8.2 Solid-phase synthesis of Py-Im polyamides. AcImPyPy- $\beta$-ImPy- $\boldsymbol{\gamma}$-ImPy- $\boldsymbol{\beta}$-ImPyPy- $\left(\mathrm{CH}_{2}\right)_{3}-\mathrm{NCH}_{3}-\left(\mathrm{CH}_{2}\right)_{3}-$ $\mathbf{N H}_{2}(\mathbf{6})$. All the Py-Im polyamides were synthesized in a stepwise reaction by Fmoc solid-phase protocol according to reported procedures ${ }^{16}$. Resulting AcImPyPy- $\beta$-ImPy- $\gamma$-ImPy- $\beta$-ImPyPy$\mathrm{CO}_{2}$-oxime resin was cleaved with $500 \mu \mathrm{L}$ of $3,3^{\prime}$-diamino- $N$ methyl-dipropylamine for overnight at $55^{\circ} \mathrm{C}$, and purified by HPLC using a YMC-Pack Pro C18 150 x $20 \mathrm{~mm}$ column $\left(\mathrm{H}_{2} \mathrm{O}\right.$ with $0.1 \% \mathrm{AcOH}$ containing $15-35 \% \quad \mathrm{CH}_{3} \mathrm{CN}$ over a linear gradient for $30 \mathrm{~min}$ at a flow rate of $6 \mathrm{~mL} / \mathrm{min}$ ). The peak around $10 \mathrm{~min}$ was collected and lyophilized to produce $6(6.3 \mathrm{mg}, 3.8$ $\mu$ mol, $18 \%)$ as a yellow powder. ${ }^{1} \mathrm{H}$ NMR (400 MHz, DMSO- $\left.d_{6}\right)$ $\delta 10.29$ (s, 2H; NH), $10.24(\mathrm{~s}, 1 \mathrm{H} ; \mathrm{NH}), 10.22$ (s, 1H; NH), 9.94 (s, 2H; NH), 9.89 (s, 4H; NH), 8.03 (br, 4H; NH), 7.45 (s, 2H; ImH), 7.42 (s, 1H; Im-H), 7.41 (s, 1H; Im-H), 7.26 (s, 2H; Py-H), 7.23 (s, 1H; Py-H), 7.21 (s, 1H; Py-H), 7.19 (s, 1H; Py-H), 7.18 (s, 1H; Py-H), 7.17 (s, 1H; Py-H), 7.11 (s, 2H; Py-H), 6.95 (s, 1H; Py-H), 6.93 (s, 1H; Py-H), 6.85 (s, 1H; Py-H), 6.83 (s, 1H; Рy-H), 3.95 (s, 3H; $\left.\mathrm{CH}_{3}\right), 3.94$ (s, 6H; $\left.\mathrm{CH}_{3}\right), 3.92\left(\mathrm{~s}, 3 \mathrm{H} ; \mathrm{CH}_{3}\right), 3.83$ (s, $\left.6 \mathrm{H} ; \mathrm{CH}_{3}\right), 3.80\left(\mathrm{~s}, 6 \mathrm{H} ; \mathrm{CH}_{3}\right), 3.79\left(\mathrm{~s}, 6 \mathrm{H} ; \mathrm{CH}_{3}\right), 3.44(\mathrm{q}, J=6.8 \mathrm{~Hz}$, $\left.6 \mathrm{H} ; \mathrm{CH}_{2}\right), 3.37$ (q, J=6.8 Hz, 4H; $\left.\mathrm{CH}_{2}\right), 3.18\left(\mathrm{~m}, 4 \mathrm{H} ; \mathrm{CH}_{2}\right), 2.58(\mathrm{t}$, $\left.J=6.8 \mathrm{~Hz}, 4 \mathrm{H} ; \mathrm{CH}_{2}\right), 2.29\left(\mathrm{br}, 4 \mathrm{H} ; \mathrm{CH}_{2}\right), 2.12\left(\mathrm{~s}, 3 \mathrm{H} ; \mathrm{CH}_{3}\right), 2.01$ (s, $\left.3 \mathrm{H} ; \mathrm{CH}_{3}\right), 1.82\left(\mathrm{~m}, 6 \mathrm{H} ; \mathrm{CH}_{2}\right)$, ESI-MS $\mathrm{m} / z$ calcd for $\mathrm{C}_{75} \mathrm{H}_{95} \mathrm{~N}_{30} \mathrm{O}_{14}$ $[\mathrm{M}+\mathrm{H}]^{+} 1639.8$; found 1639.8 .

$\mathrm{NH}_{2}-\operatorname{ImPyPy}-\boldsymbol{\beta}-\operatorname{ImPy} \boldsymbol{\gamma}-\operatorname{ImPy} \boldsymbol{\beta}-\operatorname{ImPyPy}-\left(\mathrm{CH}_{2}\right)_{3}-\mathrm{N}\left(\mathrm{CH}_{3}\right)_{2} \quad(7)$. $\mathrm{NH}_{2}$-ImPyPy- $\beta$-ImPy- $\gamma$-ImPy- $\beta$-ImPyPy- $\mathrm{CO}_{2}$-oxime resin was cleaved with $500 \mu \mathrm{L}$ of $N, N^{\prime}$-dimethylaminopropaneamine for overnight at $55{ }^{\circ} \mathrm{C}$, and purified by HPLC (the same condition as 6) to produce $7(11.1 \mathrm{mg}, 7.1 \mu \mathrm{mol}, 34 \%)$ as a yellow powder. ${ }^{1} \mathrm{H}$ NMR (400 MHz, DMSO- $d_{6}$ ) $\delta 10.29$ (s, 2H; NH), 10.24 (s, 1H; $\mathrm{NH}), 9.98$ (s, 1H; NH), 9.91 (s, 3H; NH), 9.89 (s, 2H; NH), 8.05 (br, 4H; NH), 7.45 (s, 2H; Im-H), 7.43 (s, 2H; Im-H), 7.26 (s, 1H; Py-H), 7.23 (s, 1H; Py-H), 7.21 (s, 1H; Py-H), 7.20 (s, 1H; Py-H), 7.17 (s, 2H; Py-H), 7.11 (s, 2H; Py-H), 6.95 (s, 1H; Py-H), 6.93 (s, 1H; Py-H), 6.84 (s, 1H; Py-H), 6.82 (s, 1H; Py-H), 3.94 (s, 3H; $\mathrm{CH}_{3}$ ), 3.93 (s, $3 \mathrm{H} ; \mathrm{CH}_{3}$ ), 3.92 (s, 3H; $\left.\mathrm{CH}_{3}\right), 3.86\left(\mathrm{~s}, 3 \mathrm{H} ; \mathrm{CH}_{3}\right.$ ), 3.83 (s, 3H; $\left.\mathrm{CH}_{3}\right), 3.81$ (s, 3H; $\left.\mathrm{CH}_{3}\right), 3.80\left(\mathrm{~s}, 3 \mathrm{H} ; \mathrm{CH}_{3}\right), 3.79$ (s, $\left.3 \mathrm{H} ; \mathrm{CH}_{3}\right), 3.78$ (s, 6H; $\left.\mathrm{CH}_{3}\right), 3.43\left(\mathrm{q}, \mathrm{J}=6.4 \mathrm{~Hz}, 4 \mathrm{H} ; \mathrm{CH}_{2}\right), 3.17$ (d, $\left.J=5.6 \mathrm{~Hz}, 4 \mathrm{H} ; \mathrm{CH}_{2}\right), 2.58\left(\mathrm{t}, J=6.8 \mathrm{~Hz}, 2 \mathrm{H} ; \mathrm{CH}_{2}\right), 2.34(\mathrm{t}, J=7.2$ $\left.\mathrm{Hz}, 2 \mathrm{H} ; \mathrm{CH}_{2}\right), 2.23$ (t, J=7.2 Hz, 2H; $\left.\mathrm{CH}_{2}\right), 2.12\left(\mathrm{~s}, 6 \mathrm{H} ; \mathrm{CH}_{3}\right)$, 2.10 (br, 2H; CH), 1.77 (qu, $J=6.8 \mathrm{~Hz}, 2 \mathrm{H} ; \mathrm{CH}_{2}$ ), 1.59 (qu $J=6.8$ $\mathrm{Hz}, 2 \mathrm{H} ; \mathrm{CH}_{2}$ ); ESI-MS $\mathrm{m} / \mathrm{z}$ calcd for $\mathrm{C}_{71} \mathrm{H}_{89} \mathrm{~N}_{29} \mathrm{O}_{13}[\mathrm{M}+\mathrm{H}]^{+}$ 1554.7; found 1554.8 .

\section{$\mathrm{NH}_{2}-\boldsymbol{\beta}$-ImPyPy- $\beta$-ImPy- $\boldsymbol{\gamma}$-ImPy- $\beta$-ImPyPy- $\left(\mathrm{CH}_{2}\right)_{3}-\mathrm{N}\left(\mathrm{CH}_{3}\right)_{2}$}

(8). A synthetic procedure similar to that used for the preparation of compound 7 provided $\mathbf{8}(11.5 \mathrm{mg}, 7.1 \mu \mathrm{mol}, 32 \%)$ as a yellow powder. ESI-MS $m / z$ calcd for $\mathrm{C}_{74} \mathrm{H}_{94} \mathrm{~N}_{30} \mathrm{O}_{14}[\mathrm{M}+\mathrm{H}]^{+}$1625.8; found 1625.8 .

\section{AcImPyPy- $\beta$-ImPy-(R) ${ }^{\mathrm{NH} 2} \boldsymbol{\gamma}$-ImPy- $\beta$-ImPyPy- $\left(\mathrm{CH}_{2}\right)_{3}-\mathrm{N}\left(\mathrm{CH}_{3}\right)_{2}$} (9). AcImPyPy- $\beta$-ImPy-(R) ${ }^{\mathrm{NHBoc}} \gamma$-ImPy- $\beta$-ImPyPy-CO $\mathrm{CO}_{2}$-oxime resin was cleaved with $500 \mu \mathrm{L}$ of $N, N^{\prime}-$ dimethylaminopropaneamine for overnight at $55{ }^{\circ} \mathrm{C}$, and purified by HPLC (the same condition as $\mathbf{6}$ ), to produce Boc-protected $\mathbf{9}$. After deprotection Boc group with 20\% TFA in dichloromethane, 
9 was obtained $(9.3 \mathrm{mg}, 5.8 \mu \mathrm{mol}, 26 \%)$ as a yellow powder. ESIMS $m / z$ calcd for $\mathrm{C}_{73} \mathrm{H}_{91} \mathrm{~N}_{30} \mathrm{O}_{14}[\mathrm{M}+\mathrm{H}]^{+}$1611.7; found 1611.8.

AcImPyPy- $\boldsymbol{\beta}$-ImPy- $\boldsymbol{\gamma}$-ImPy- $\boldsymbol{\beta}$-Im- $\mathrm{CO}_{2} \mathrm{H} \quad$ (10). AcImPyPy- $\beta$ ImPy- $\gamma$-ImPy- $\beta$-Im- $\mathrm{CO}_{2}$-Wang resin was cleaved with $1 \mathrm{~mL}$ of TFA/water/TIS $(95 / 2.5 / 2.5 ; \mathrm{v} / \mathrm{v} / \mathrm{v})$ for $1 \mathrm{~h}$ at room temperature. After ether precipitation, 10 was obtained $(24.2 \mathrm{mg}, 19 \mu \mathrm{mol}$, $53 \%$ ) as a yellow powder. 10 was used for the synthesis of polyamide-seco-CBI conjugate $\mathbf{5}$ without further purification. ESI-TOF-MS $m / z$ calcd for $\mathrm{C}_{56} \mathrm{H}_{66} \mathrm{~N}_{23} \mathrm{O}_{13}[\mathrm{M}+\mathrm{H}]^{+}$1268.52; found 1268.52 .

\section{AcImPyPy- $\beta$-ImPy- $\gamma$-ImPy- $\beta$-ImPyPy- $\left(\mathrm{CH}_{2}\right)_{3}-\mathrm{NCH}_{3}-\left(\mathrm{CH}_{2}\right)_{3}-$}

NH-Chlorambucil (1). To a solution of compound 6 (6.6 mg, 4.0 $\mu \mathrm{mol})$, PyBOP (6.1 mg, $12 \mu \mathrm{mol})$, and chlorambucil (4.3 mg, 14 $\mu \mathrm{mol})$ in DMF $(100 \mu \mathrm{L})$, DIEA $(2.4 \mu \mathrm{L}, 14 \mu \mathrm{mol})$ was added. The reaction mixture was incubated overnight at room temperature. Evaporation of the solvent gave yellow crude, which was washed with ether ( $1 \mathrm{~mL} \times 2)$ and dichloromethane (1 mL x 2). HPLC purification was performed using a Chemcobond 5-ODS- $\mathrm{H} 10 \mathrm{x}$ $150 \mathrm{~mm}$ column $\left(\mathrm{H}_{2} \mathrm{O}\right.$ with $0.1 \%$ AcOH containing $0-66 \%$ $\mathrm{CH}_{3} \mathrm{CN}$ over a linear gradient for $30 \mathrm{~min}$ at a flow rate of 3 $\mathrm{mL} / \mathrm{min}$ ), The peak around $17 \mathrm{~min}$ was collected and lyophilized to produce conjugate 1 was obtained ( $2.7 \mathrm{mg}, 1.4 \mu \mathrm{mol}, 35 \%)$ as a white powder. 1 was used in the DNA alkylation reaction. Synthetic procedures were similar to that used for the preparation of compounds 1-4 from polyamides 6-9. ${ }^{1} \mathrm{H}$ NMR $(400 \mathrm{MHz}$, $\left.\mathrm{DMSO}_{-}\right) \oint 10.38(\mathrm{~s}, 2 \mathrm{H} ; \mathrm{NH}), 10.31(\mathrm{~s}, 1 \mathrm{H} ; \mathrm{NH}), 10.28(\mathrm{~s}, 1 \mathrm{H}$; $\mathrm{NH}), 9.95$ (s, 3H; NH), 9.92 (s, 1H; NH), 9.88 (s, 2H; NH), 8.08 (br, 5H; NH), 7.44 (s, 2H; Im-H), 7.42 (s, 1H; Im-H), 7.41 (s, 1H; Im-H), 7.26 (s, 2H; Py-H), 7.20 (s, 1H; Py-H), 7.18 (s, 1H; Py-H), 7.12 (s, 2H; Py-H), 6.98 (s, 1H; Py-H), 6.96 (m, 2H; benzene-H), 6.94 (s, 1H; Py-H), 6.85 (s, 1H; Py-H), 6.83 (s, 1H; Py-H), 6.63 (m, 2H; benzene-H), $3.93\left(\mathrm{~s}, 9 \mathrm{H} ; \mathrm{CH}_{3}\right), 3.92\left(\mathrm{~s}, 3 \mathrm{H} ; \mathrm{CH}_{3}\right), 3.83(\mathrm{~s}$, $\left.3 \mathrm{H} ; \mathrm{CH}_{3}\right), 3.80$ (s, 9H; $\left.\mathrm{CH}_{3}\right), 3.79\left(\mathrm{~s}, 6 \mathrm{H} ; \mathrm{CH}_{3}\right), 3.67(\mathrm{~m}, 8 \mathrm{H}$; $\left.\mathrm{CH}_{2}\right), 3.45\left(\mathrm{~m}, 6 \mathrm{H} ; \mathrm{CH}_{2}\right), 3.19\left(\mathrm{~m}, 4 \mathrm{H} ; \mathrm{CH}_{2}\right), 2.66\left(\mathrm{~m}, 2 \mathrm{H} ; \mathrm{CH}_{2}\right)$, $2.58\left(\mathrm{~m}, 4 \mathrm{H} ; \mathrm{CH}_{2}\right), 2.32\left(\mathrm{~m}, 6 \mathrm{H} ; \mathrm{CH}_{2}\right), 2.11\left(\mathrm{~s}, 3 \mathrm{H} ; \mathrm{CH}_{3}\right), 2.01(\mathrm{~s}$, $\left.3 \mathrm{H} ; \mathrm{CH}_{3}\right), 1.77\left(\mathrm{~m}, 8 \mathrm{H} ; \mathrm{CH}_{2}\right)$; ESI-TOF-MS $\mathrm{m} / \mathrm{z}$ calcd for $\mathrm{C}_{89} \mathrm{H}_{112} \mathrm{Cl}_{2} \mathrm{~N}_{31} \mathrm{O}_{15}[\mathrm{M}+\mathrm{H}]^{+}$1924.83; found 1924.96 .

\section{Chlorambucil-NH-ImPyPy- $\beta$-ImPy- $\boldsymbol{\gamma}$-ImPy- $\boldsymbol{\beta}$-ImPyPy-}

$\left(\mathbf{C H}_{2}\right)_{3}-\mathbf{N}\left(\mathbf{C H}_{3}\right)_{2}$ (2). $\mathbf{2}$ was obtained as a white powder (1.3 mg, $0.71 \mu \mathrm{mol}, 24 \%$ ) from polyamide $7 .{ }^{1} \mathrm{H}$ NMR (400 MHz, DMSO$\left.d_{6}\right) \delta 10.28(\mathrm{~s}, 2 \mathrm{H}$; NH), $10.24(\mathrm{~s}, 1 \mathrm{H} ; \mathrm{NH}), 10.20(\mathrm{~s}, 1 \mathrm{H} ; \mathrm{NH})$, 9.97 (s, 1H; NH), 9.95 (s, 1H; NH), 9.90 (s, 3H; NH), 9.89 (s, 2H; NH), 8.06 (br, 4H; NH), 7.45 (s, 3H; Im-H), 7.42 (s, 1H; Im-H), 7.25 (s, 2H; Py-H), 7.21 (s, 1H; Py-H), 7.19 (s, 1H; Py-H), 7.17 (s, 2H; Py-H), 7.11 (s, 1H; Py-H), 7.02 (d, J=8.4 Hz, 2H; benzene-H), 6.95 (s, 1H; Py-H), 6.93 (s, 1H; Py-H), 6.85 (s, 1H; Py-H), 6.82 (s, $1 \mathrm{H}$; Py-H), 6.65 (d, J=8.0 Hz, 2H; benzene-H), 3.94 (s, 3H; $\mathrm{CH}_{3}$ ), 3.93 (s, 6H; $\left.\mathrm{CH}_{3}\right), 3.92$ (s, 3H; $\left.\mathrm{CH}_{3}\right), 3.83\left(\mathrm{~s}, 6 \mathrm{H} ; \mathrm{CH}_{3}\right), 3.80$ (s, $\left.6 \mathrm{H} ; \mathrm{CH}_{3}\right), 3.79$ (s, 6H; $\left.\mathrm{CH}_{3}\right), 3.68\left(\mathrm{~s}, 6 \mathrm{H} ; \mathrm{CH}_{3}\right), 3.43$ (q, $J=6.4 \mathrm{~Hz}$, $4 \mathrm{H} ; \mathrm{CH}_{2}$ ), 3.17 (d, J=5.6 Hz, 4H; $\mathrm{CH}_{2}$ ), 3.00 (br, $4 \mathrm{H} ; \mathrm{CH}_{2}$ ), 2.56 (t, $J=7.2 \mathrm{~Hz}, 2 \mathrm{H} ; \mathrm{CH}_{2}$ ), 2.32 (t, $\left.J=8.0 \mathrm{~Hz}, 2 \mathrm{H} ; \mathrm{CH}_{2}\right), 2.17$ (br, $2 \mathrm{H}$; $\left.\mathrm{CH}_{2}\right), 1.78$ (m, 2H; $\mathrm{CH}_{2}$ ), $1.72\left(\mathrm{~m}, 2 \mathrm{H} ; \mathrm{CH}_{2}\right), 1.61$ (m, 2H; $\mathrm{CH}_{2}$ ); ESI-TOF-MS $m / z$ calcd for $\mathrm{C}_{85} \mathrm{H}_{105} \mathrm{Cl}_{2} \mathrm{~N}_{30} \mathrm{O}_{14}[\mathrm{M}+\mathrm{H}]^{+}$1839.78; found 1839.85 .
Chlorambucil-NH- $\boldsymbol{\beta}$-ImPyPy- $\boldsymbol{\beta}$-ImPy- $\boldsymbol{\gamma}$-ImPy- $\boldsymbol{\beta}$-ImPyPy-

$\left(\mathbf{C H}_{2}\right)_{3}-\mathbf{N}\left(\mathbf{C H}_{3}\right)_{2}$ (3). 3 was obtained as a white powder $(1.3 \mathrm{mg}$, $0.71 \mu \mathrm{mol}, 24 \%$ ) from polyamide 8. ESI-TOF-MS $\mathrm{m} / z$ calcd for $\mathrm{C}_{88} \mathrm{H}_{110} \mathrm{Cl}_{2} \mathrm{~N}_{31} \mathrm{O}_{15}[\mathrm{M}+\mathrm{H}]^{+}$1910.82; found 1910.81 .

AcImPyPy- $\boldsymbol{\beta}$-ImPy-(R) ${ }^{\mathrm{NH}-c h l o r a m b u c i l} \boldsymbol{\gamma}$-ImPy- $\boldsymbol{\beta}$-ImPyPy- $\left(\mathrm{CH}_{2}\right)_{\mathbf{3}^{-}}$ $\mathbf{N}\left(\mathbf{C H}_{3}\right)_{2}$ (4). 4 was obtained as a white powder (3.9 mg, $2.1 \mu \mathrm{mol}$, $71 \%$ ) from polyamide 9. ESI-TOF-MS $\mathrm{m} / \mathrm{z}$ calcd for $\mathrm{C}_{87} \mathrm{H}_{108} \mathrm{Cl}_{2} \mathrm{~N}_{31} \mathrm{O}_{15}[\mathrm{M}+\mathrm{H}]^{+}$1896.80; found 1896.81 .

AcImPyPy- $\boldsymbol{\beta}$-ImPy- $\boldsymbol{\gamma}$-ImPy- $\boldsymbol{\beta}$-Im-Indole-seco-CBI (5). 5 was synthesized according to reported procedure from polyamide $\mathbf{1 0}^{16}$. HPLC purification was performed using a Chemcobond 5-ODS-H 4.6 x $150 \mathrm{~mm}$ column $\left(\mathrm{H}_{2} \mathrm{O}\right.$ with $0.1 \% \mathrm{AcOH}$ containing $35-75 \%$ $\mathrm{CH}_{3} \mathrm{CN}$ over a linear gradient for $20 \mathrm{~min}$ at a flow rate of 1 $\mathrm{mL} / \mathrm{min}$ ), The peak around $12 \mathrm{~min}$ was collected and lyophilized to produce conjugate 5 was obtained $(0.5 \mathrm{mg}, 0.3 \mu \mathrm{mol}, 5 \%)$ as a brown powder. 5 was used in the DNA alkylation reaction. ESITOF-MS $m / z$ calcd for $\mathrm{C}_{78} \mathrm{H}_{82} \mathrm{ClN}_{26} \mathrm{O}_{14}[\mathrm{M}+\mathrm{H}]^{+}$1641.62; found 1641.64 .

\subsection{Cloning of 209 bp DNA fragments.}

All DNA fragments and primers for cloning or DNA amplification were purchased from SIGMA genosys. The $32 \mathrm{bp}$ DNA fragment (ODN1: 5'-AAGCAGTCAAAAACCGGAAAGCAGTCTTTTTA-3', and 5'-AAAAAGACTGCTTTCCGGTTTTTGACTGCTTA-3') were ligated into pGEM-T Easy vectors (Promega), Escherichia coli DH5 $\alpha$ competent cells (Toyobo) were transformed and cultured on LB plates with $100 \mu \mathrm{g} / \mathrm{mL}$ ampicillin and $32 \mu \mathrm{g} \mathrm{X}$-gal $/ 400 \mu \mathrm{g}$ IPTG overnight at $37^{\circ} \mathrm{C}$. White colonies were identified by colony direct polymerase chain reaction (PCR) in $20 \mu \mathrm{L}$ the reaction mixtures containing $250 \mathrm{nM}$ of primer set (T7: 5'-TAATACGACTCACTATAGGG-3', sp6: 5'-GATTTAGGTGACACTATAG-3'), $200 \mu \mathrm{M}$ of deoxynucleotide triphosphates (Sigma Aldrich), 2 units Taq DNA polymerase and $1 \mathrm{X}$ ThermoPol Reaction Buffer (New England Bio Labs). The reaction mix was incubated at $95{ }^{\circ} \mathrm{C}$ for 5 min then followed by 30 incubation cycles of $95{ }^{\circ} \mathrm{C}$ for $30 \mathrm{sec}, 55^{\circ} \mathrm{C}$ for $30 \mathrm{sec}$, and $72{ }^{\circ} \mathrm{C}$ for $30 \mathrm{sec}$ with final extension step of $72{ }^{\circ} \mathrm{C}$ for $7 \mathrm{~min}$. The appropriate colony was selected for transfer to $5 \mathrm{~mL}$ of $\mathrm{LB}$ medium with $100 \mu \mathrm{g} / \mathrm{mL}$ ampicillin and cultured overnight at $37^{\circ} \mathrm{C}$. The plasmids with inserts were extracted using GenElute ${ }^{\mathrm{TM}}$ Plasmid Miniprep Kit (Sigma Aldrich) and identified by PCR. (program and reaction mixtures were the same as above)

8.4 Preparation of 5'-Texas Red-labeled DNA Fragments and High Resolution Gel Electrophoresis.

The 5'-Texas Red-modified 209 bp DNA fragment was prepared by PCR with 5'-TexasRed-modified sp6 and T7 primers from 1 $\mathrm{ng} / \mu \mathrm{L}$ of the $32 \mathrm{bp}$ fragments inserted pGEM-T Easy vector (program and reaction mixtures were the same as above). Fragments were purified by GenElute ${ }^{\mathrm{TM}}$ PCR Clean-up Kit (Sigma Aldrich), and their concentrations were determined by UV absorption.

\subsection{High-Resolution Gel Electrophoresis.}

The 5'-Texas Red-labeled DNA fragments $(10 \mathrm{nM})$ were alkylated by various concentration of conjugates $1-5$ in $10 \mu \mathrm{L}$ of 5 $\mathrm{mM}$ sodium phosphate buffer $(\mathrm{pH} 7.0)$ containing $10 \%$ DMF at $23{ }^{\circ} \mathrm{C}$. After incubation for $18 \mathrm{~h}$, the reaction was quenched by the 
addition of $10 \mu \mathrm{g}$ of calf thymus DNA and heating for $10 \mathrm{~min}$ at $95{ }^{\circ} \mathrm{C}$. The solution was concentrated by vacuum centrifugation. The pellet was dissolved in $7 \mu \mathrm{L}$ loading dye (formamide with fuschin red), heated at $95{ }^{\circ} \mathrm{C}$ for $25 \mathrm{~min}$, and then immediately cooled to $0{ }^{\circ} \mathrm{C}$. A $2 \mu \mathrm{L}$ aliquot was subjected to electrophoresis on a $6 \%$ denaturing polyacrylamide gel using a Hitachi DNA Sequencers.

\subsection{Analysis of inhibition of the growth of the human K562 cell} line.

Detailed assay procedures were reported previously ${ }^{25}$. The human lymphocyte K562 cells were cultured in RPMI-1640 medium supplemented with $10 \%$ heat-inactivated fetal bovine serum, penicillin $(100 \mathrm{IU} / \mathrm{mL})$, and streptomycin $(100 \mu \mathrm{g} / \mathrm{mL})$ at $37{ }^{\circ} \mathrm{C}$ in a humidified atmosphere of $95 \%$ air and $5 \% \mathrm{CO}_{2}$. Colorimetric assays with the WST-8 (Dojindo, Kumamoto, Japan) were carried out in 96-well plates. In the logarithmic growth phase, $5 \times 10^{3}$ cells were plated into each well in $50 \mu \mathrm{L}$ of culture medium. Then, medium $(50 \mu \mathrm{L})$ containing various concentrations of compounds 1-5 or $1 \%$ DMSO $(50 \mu \mathrm{L})$ as a control was added to the wells. After treatment with the compounds for $48 \mathrm{~h}$, WST-8 reagent (10 $\mu \mathrm{L}$ ) was added to each well, and the cells were incubated for $3 \mathrm{~h}$ at $37{ }^{\circ} \mathrm{C}$. Absorbance was measured at 450 and $600 \mathrm{~nm}$ using an MPR-A4I microplate reader (Tosoh). The absorbances of the control $(\mathrm{C})$, treated wells $(\mathrm{T})$ and treated wells at time $0\left(\mathrm{t}_{0}\right)$ were measured. The $\mathrm{GI}_{50}$ was calculated as $100 \times\left[\left(\mathrm{T}-\mathrm{t}_{0}\right) /\left(\mathrm{C}-\mathrm{t}_{0}\right)\right]=50$.

\section{Acknowledgments}

Mr. M. Minoshima was supported by a research fellowship of the Global COE (Center of Excellence) program, International Center for Integrated Research and Advanced Education in Material Science, Kyoto University, Japan. We would like to thank Ms. K. Hashiya for the purification of the polyamides. This work was supported by a Grant-in-Aid for Priority Research from the Ministry of Education, Culture, Sports, Science, and Technology, Japan and SORST of Japan Science and Technology (JST).

\section{References}

1. Hurley, L. H. Nat. Rev. Cancer 2002, 2, 188-200.

2. Rajski, S. R.; Williams, R. M. Chem. Rev. 1998, 98, 2723-2795.

3. (a) Baker B. F.; Dervan, P. B. J. Am. Chem. Soc. 1985, 107, 8266-8268. (b) Broggini, M.; Erba, E.; Ponti, M.; Ballinari, D.; Ceroni, C.; Spreafico, F.; D'Incaici, M. Cancer Res. 1991, 51, 199-204. (c) Broggini, M.; Coley, H. M.; Mongelli, N.; Pesenti, E.; Wyatt, M. D; Hartley, J. A.; D'Incaici, M. Nucleic Acids Res. 1995, 23, 81-87.

4. (a) Hurley, L. H.; Lee, C-S.; McGovren, J. P.; Warpehoski, M. A.; Mitchell, M. A.; Kelly, R. C.; Aristoff, P. A. Biochemistry 1988, 27, 3886-3892. (b) Yasuzawa, T.; Muroi, K.; Ichimura, M.; Takahashi, I.; Ogawa, T.; Takahashi, K.; Sano, H.; Saitoh, Y. Chem. Pharm. Bull. 1995, 43, 378-391.

5. For recent review, see: (a) Dervan, P. B.; Poulin-Kerstien, A. T.; Fechter, E. J.; Edelson, B. S. Top Curr. Chem. 2005, 253, 1-31. (b) Dervan, P. B.; Edelson, B. S. Curr. Opin. Str. Biol. 2003, 13, 284-299.

6. (a) Gottesfeld, J. M., Neely, L.; Trauger, J. W.; Baird., E. E.; Dervan, P. B. Nature 1997, 387, 202-205. (b) Olenyuk, B. Z.; Zhang, G-J., Klco, J. M.; Nickols, N. G.; Kaelin, Jr, W. G.; Dervan, P. B. Proc. Natl. Acad. Sci. USA 2004, 101, 16768-16873. (c) Nickols, N. G.; Dervan, P. B. Proc. Natl. Acad Sci. USA 2007, 104, 10418-10423.

7. For recent review, see: Bando, T.; Sugiyama, H. Acc. Chem. Res. 2006, 39, 935-944.
8. (a) Boger, D. L.; Johnson, D. S. Angew. Chem. Int. Ed. 1996, 35, 1438-1474 (b) Boger, D. L.; Munk, S. A. J. Am. Chem. Soc. 1992, 114, 5487-5496.

9. Bando, T.; Iida, H.; Tao, Z-F.; Narita, A.; Fukuda, N.; Yamori, T.; Sugiyama, H. Chem. Biol. 2003, 10, 751-758.

10. (a) Bando, T.; Sasaki, S.; Minoshima, M.; Shinohara, K.; Dohno, C.; Narita, A.; Sugiyama, H. Bioconjugate Chem. 2006, 17, 715-720. (b) Minoshima, M.; Bando, T.; Sasaki, S.; Shinohara, K.; Shimizu, T.; Fujimoto, J.; Sugiyama, H. J. Am. Chem. Soc. 2007, 129, 5384-5390. (c) Sasaki, S.; Bando, T.; Minoshima, M.; Shinohara, K.; Sugiyama, H. Chem. Eur. J. 2008, 18, 864-870.

11. Oyoshi, T.; Kawakami, W.; Narita, A.; Bando, T.; Sugiyama, H. J. Am. Chem. Soc. 2003, 125, 4752-4754.

12. (a) Shinohara, K.; Narita, A.; Oyoshi, T.; Bando, T.; Teraoka, H.; Sugiyama, H. J. Am. Chem. Soc. 2004, 126, 5113-5118. (b) Shinohara, K.; Sasaki, S.; Minoshima, M.; Bando, T.; Sugiyama, H. Nucleic Acids Res. 2006, 34, 11891195.

13. Dickinson, L. A.; Burnett, R.; Melander, C.; Edelson, B. S.; Arora, P. S.; Dervan, P. B.; Gottesfeld, J. M. Chem. Biol. 2004, 11, 1583-1594.

14. (a) Alvarez, D.; Chou, C. J.; Latella, L.; Zeitlin, S. G.; Ku, S.; Puri, P. L.; Dervan, P. B.; Gottesfeld, J. M. Cell Cycle 2006, 5, 1537-1548. (b) Chou, C. J.; Farkas, M. E.; Tsai, S. M.; Alvarez, D.; Dervan, P. B.; Gottesfeld, J. M. Mol. Cancer Ther. 2008, 7. 769-778. (c) Chou, C. J.; O'Hare, T; Lefebvre, S.; Alvarez, D.; Tyner, J. W.; Eide, C. A.; Druker, B. J.; Gottesfeld, J. M. PLOS ONE 2008, 3, e3593-3600.

15. Tsai, S. M.; Farkas, M. E.; Chou, C. J.; Gottesfeld, J. M.; Dervan, P. B. Nucleic Acids Res. 2007, 35, 307-316.

16. (a) Baird, E. E.; Dervan, P. B. J. Am. Chem. Soc. 1996, 118, 6141-6146. (b) Wurtz, N. R.; Turner, J. M.; Baird, E. E.; Dervan, P. B. Org. Lett. 2001, 3 1201-1203. (c) Belitsky, J. M., Nguyen, D. H., Wurtz, N. R., Dervan, P. B. Bioorg. Med. Chem. 2002, 10, 2767-2774.

17. Sasaki, S.; Bando, T.; Minoshima, M.; Shimizu, T.; Shinohara, K.; Takaoka, T.; Sugiyama, H. J. Am. Chem. Soc. 2006, 128, 12162-12168.

18. (a) Bando, T.; Narita, A.; Saito, I.; Sugiyama, H. Chem. Eur. J. 2002, 8, 4781-4790. (b) Bando, T.; Narita, A.; Saito, I.; Sugiyama, H. J. Am. Chem. Soc. 2003, 125, 3471-3485. (c) Bando, T.; Narita, A.; Asada, K.; Ayame, H.; Sugiyama, H. J. Am. Chem. Soc. 2004, 126, 8948-8955. (d) Bando, T.; Narita, A.; Sasaki, S.; Sugiyama, H. J. Am. Chem. Soc. 2005, 127, 13890-13895.

19. Farkas, M. E.; Tsai, S. M.; Dervan, P. B. Bioorg. Med. Chem. 2007, 15, 6927-6936.

20. (a) Chang, A. Y.; Dervan, P. B. J. Am. Chem. Soc. 2000, 122, 4856-4864 (b) Wurtz, N. R.; Dervan, P. B. Chem. Biol. 2000, 7, 153-161. (c) Wang, YD.; Dziegielewski, J.; Wurtz, N. R.; Dziegielewska, B.; Dervan, P. B.; Beerman, T. A. Nucleic Acids Res. 2003, 31, 1208-1215.

21. (a) Bosanquet, A. G. Cancer Chemother. Pharmacil. 1985, 14, 83-95. (b) Giraud, I., Rapp, M.; Maurizis, J-C.; Madelmont, J-C. J. Med. Chem. 2002, $45,2116-2119$.

22. Edelson, B. S.; Best, T. P.; Olenyuk, N. G.; Nickols, N. G.; Doss, R. M.; Foister, S.; Heckel, A.; Dervan, P. B. Nucleic Acids Res. 2004, 32, 2802 2818.

23. Brooks, N.; McHugh, P. J.; Lee, M.; Hartley, J. A. Chem. Biol. 2000, 7, 659-668.

24. Bando, T.; Narita, A.; Iwai, A.; Kihara, K.; Sugiyama, H. J. Am. Chem. Soc. 2004, 126, 3406-3407.

25. Shinohara, K.; Bando, T.; Sasaki, S.; Sakakibara, Y.; Minoshima, M.; Sugiyama, H. Cancer Sci. 2006, 97, 219-225. 
